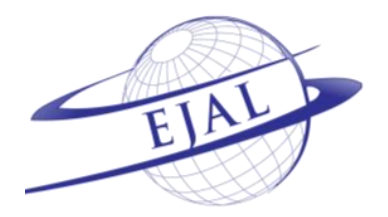

Available online at www.ejal.eu

\title{
Review of English Language Education Policy in The Middle East and North Africa
}

\author{
Süleyman GÜN a * (D) \\ ${ }^{a}$ Burdur Mehmet Akif Ersoy University, İstiklal Campus, Burdur, 15030, Turkey
}

Received 12 January 2018 | Received in revised form 24 February 2018 | Accepted 04 August 2018

\begin{abstract}
APA Citation:
Gün, S. (2018). Review of English language education policy in the Middle East and North Africa. Eurasian Journal of Applied Linguistics, 4(2), 409-415. doi: 10.32601/ejal.464207
\end{abstract}

\begin{abstract}
English Language Education Policy in the Middle East and North Africa, Robert Kirkpatrick (Ed.). Springer International Publishing AG. Cham, Switzerland (2017). ISBN 978-3-319-46776-4 (Hardcover), ISBN 978-3-319-46778-8 (eBook).

(C) 2018 EJAL \& the Authors. Published by Eurasian Journal of Applied Linguistics (EJAL). This is an open-access article distributed under the terms and conditions of the Creative Commons Attribution license (CC BY-NC-ND) (http://creativecommons.org/licenses/by-nc-nd/4.0/).
\end{abstract}

Keywords: English Education Policy; English Language Education, Middle East and North Africa.

For nearly the last 50 years, notable changes have been observed in issues of language teaching and learning parallel to the spread of English as a global language which led to a confrontation between a spreading global language and indigenous local languages. For this reason, some areas of interest such as accepting multilingualism, tolerance to language rights, national identity and national language, globalization, English as a medium of instruction, world Englishes have become more popular. Therefore, the field of language policy and planning has turned into an active field with the growing interest and produced a vast body of research literature.

Similarly, the international book, English Language Education Policy in the Middle East and North Africa, edited by Robert Kirkpatrick is published in order to give a detailed account of English language policy in non-European countries where English is used as a foreign language.

With the aim of setting the scene, the authors of the first chapter, Robert Kirkpatrick and Osman Z. Barnawi, make an introduction and provide an insight into English Language Education Policy and national language policies in 15 countries of the Middle East and North Africa (MENA). In relation with the educational and economic aims of the MENA countries, perceived language abilities of individuals are

\footnotetext{
* Corresponding author. Tel: +90-248-213-4320

E-mail address: $\underline{\text { sgun@mehmetakif.edu.tr }}$
} 
taken into consideration and the authors put emphasis on the relation between aims and current situation. Moreover, the authors discuss the increasing rates of using English and its effects on national languages and national identity in relation to English education policies in action, curriculums in national dimensions, teacher training and education, pedagogies, and evaluations in a detailed manner. Upon the explanation of Tsui and Tollefson (2007) about the dependence of globalization on technology and English, it is underlined that English has emerged as an active member in the spread of political, social and educational norms and fostered economic globalization. There is a two-way relationship between English and globalization as they affect each other mutually. To illustrate, the authors draw a parallelism between parents of young learners at kindergartens of a MENA country demanding English practices for their kids and scholars publishing articles in English academic journals have started to receive reputations. With all these considerations, English is regarded more as the international or global language every single day.

After the introduction chapter, the book is composed of 15 chapters about English language education policy of 15 MENA countries of Bahrain, Egypt, Iran, Israel, Kuwait, Libya, Morocco, Oman, Palestine, Qatar, Saudi Arabia, Syria, Turkey, Tunisia, and the United Arab Emirates (UAE). The editor indicates that although all those 15 countries take place in the MENA region, there are certain distinct differences among them. To specify, in most of those countries, Arabic is the first language but some have their national mother languages.

In chapter two, "English Education Policy in Bahrain - A Review of K-12 and Higher Education Language Policy in Bahrain" by Amir Abou-El-Kheir and Paul MacLeod, the authors give a short introduction about 5000-year long history of Bahrain, population structure and political situations in the country as well as its economic and political relationship with Britain. English education policy in Bahrain is identified separately for primary, intermediate, secondary schools and higher education institutes. The remarkable thing is that English is introduced in the first grade of primary schools in Bahrain. Afterwards, Bahrain's K-12 and higher education systems are described with their strengths, weaknesses, and limitations and compared with the education policies of the neighboring countries. Then, the authors focus on some controversial issues in English language policy in Bahraini K12 and higher education system with reference to the dilemma between the economic advantages of English and promotion of cultural, religious, historical and linguistic aspects of the country. After explaining the current situation, the future of education policy in Bahrain is mentioned. The authors conclude the chapter by underlining the achievements in developmental stages of Bahraini education system and making six suggestions in order to develop it further in the future.

In chapter three titled "English Education Policy at the Pre-university Stages in Egypt: Past, Present and Future Directions" the author Muhammad M.M. Abdel Latif limits the chapter with primary, preparation and secondary stages and excludes higher education stage in Egyptian education system and focuses on English education policy in relation with past experiences, present practices, and future 
vision. The existence of English courses in Egyptian education system is indicated in the chapter, however; the author indicates that the position of English is unstable because of educational reforms with the political alterations throughout the country. As the conclusion of the chapter, the author specifies a number of suggestions for English education policy of Egypt in the future.

In chapter four, "English Education in Iran: From Ambivalent Policies to Paradoxical Practices", Ferdows Aghagolzadeh and Hossein Davari focus on the aspects of English language education at schools, universities, private English institutes in Iran as well as American and British associations in relation with turmoil in national education policy and conditions in Iran before and after the Islamic Revolution in 1979. It is indicated that Iran passed through a radical regime change and turned from a country regarding English as a language of prestige and globalization with strong ties with the west on economic and educational fields to a country regarded as anti-Western and anti-imperialistic one accepting English as the language of enemies. The returns of that radical change in English language education are under investigation in the chapter.

In chapter five entitled "English Education Policy in Israel" by Iair G. Or and Elana Shohamy, the state of the English is handled with the historical development of the country. The multilingual structure of the habitants of the territory of modern-day Israel is indicated with the following languages used throughout the background of the territory; Arabic and Turkish mainly before the nineteenth century; Hebrew, Aramaic, Judeo-Spanish, Judeo-Arabic, and Yiddish as a group of additional languages; and Coptic, Greek, Latin, Russian, and German as liturgical and vernacular languages. The chapter talks about the status of English in Israeli society and Israeli education system. Additionally, English is regarded as the global language, a lingua franca, among the Jews from different countries and a means for success and social mobility in today's Israel. Yet, it is also claimed that there has been inequality between Israeli people from different socio-economical and religious groups for learning and using English to make contact with Jewish people from different countries. The authors conclude that English has a lot of social meanings, uses, and manifestations in Israel, but not all inhabitants of Israel have the same access to English. Therefore, some factors such as socio-economic status, living place, country of origin, and preferences of TV viewing may affect proficiency of English.

Marta Maria Tryzna and Hussain Al Sharoufi entitle chapter six as "English Language Education Policy in Kuwait" and they examine English language education policy of Kuwait as a Gulf country in two perspectives; historical and contemporary. They introduce Kuwait in relation with geographical, economic, sociological, educational and international features of the country. The status of English is discussed in linguistically diverse population as the two-thirds of the population is an expatriate community and they have arrived from different countries. The case of the English education at schools and higher education institutes in Kuwait, English language curriculum and English teacher education policy are the central discussion topics throughout the chapter. The authors make a conclusion by highlighting the 
contradictions. English has been receiving a status of unofficial language in Kuwait, but the population has certain confusions about the function of the language. Ministry of Education in Kuwait makes an effort to develop English language education, but the graduates of public schools do not have a high level of English proficiency. As a conclusion, the authors underline the apparent contradictions in issues of English across the country and state that although Kuwait has a well-designed and coherent policy of English language, the practice of the policy is unsatisfactory.

In chapter seven entitled "English Language Teaching in Libya After Gaddafi" Abed Aloreibi and Michael D. Carey present the English language policy of the country in association with cultural, social, and political characteristics of the Libyan society. They show interest in the transform from English education which was based on grammar-based curricula to the new English education model which is based on Communicative Language Teaching principles in 2000. The authors generally talk about the traits of the country, especially the effects of the tribal nature of society with over 2000 tribes and the influence of Gaddafi as a leader, the conditions of teachers and students, colonialism and attitudes towards English and English methodology. It is concluded that English has failed to become a Lingua Franca in Libya even though it is required in the industrial and economic situation of the country.

In chapter eight, "English Education Policy and Practice in Morocco", Mohammed Errihani examines English language education policy in the multi-lingual context of the country. He indicates that the existence of the following languages with several variations turns the country to a multi-lingual and multi-cultural one; Arabic language with Classical Arabic, Darija (Moroccan Arabic vernacular), Modern Standard Arabic, Berber (Tamazight), French, Spanish, and English. Throughout the chapter, the author tries to scrutinize English language policy in Morocco in relation with the policy of Arabization, educational reforms, Najah program as an emergency plan, socio-economic structure, the stakeholders of English teaching and learning process. As a conclusion, the author draws attention to the dysfunctional state of the education system in the country and indicates that there occurs a strong alteration in Morocco's language education policy so English gains more space in the linguistic scene of Morocco.

In chapter nine, "English Education Policy in Oman", by Khalid Salim Al-Jardani, the position of English language education in the country is discussed in two aspects; in governmental view and in society view. This chapter is a comprehensive one as it examines the education system from primary school education to tertiary school education. Besides covering all levels of formal education, the chapter also talks about English language teaching methodology, curriculum with the evaluation of the present curriculum, and teacher training program. The chapter focuses on certain challenges threatening the youth in the process of establishing a better life and work. Before completing the chapter, the author talks about the practice of one textbook for all government schools. 
The title of chapter ten is "The English Language Teaching Situation in Palestine" and in this chapter Robert Bianchi and Anwar Hussein - Abdel Razeq speak on the special and dynamic sociolinguistic structure of Palestine with the existence of several languages such as Arabic, Turkish, French, and English at different periods and the effects of that variety on different entities of society like economy, politics, culture, and ineluctably education system. This chapter presents an extensive explanation of English language education and related factors. After the brief linguistic history and changing ruling systems of the country, developmental stages of English in the country are expressed in a year-based description. The chapter also presents information about the aspects of public school grades 1-12 and English courses at the universities. Additionally, the chapter informs the readers about related curriculum in the country, assessment, and evaluation processes, and provides information about the norms and challenges and gives some recommendations for English language teacher training by involving both pre-service and in-service English teacher training programs in a detailed manner.

In chapter eleven, "Qatar's English Education Policy in K-12 and Higher Education: Rapid Development, Radical Reform and Transition to a New Way Forward", Paul MacLeod and Amir Abou-El-Kheir concentrate on the educational reform and development program which were put into practice in the recent past years and how Qatar as a small peninsula country in the Arabian Gulf with a few schools and no universities has transformed into a reformist country with a comprehensive K-12 system, three technical colleges, and 15 universities. Afterwards, the process of replacing English medium of instruction with Arabic and returns of that policy change are discussed within the context of Qatar. The chapter presents detailed information about the past and present aspects of K-12 and higher education systems in the country and presents some future projections with advantages and disadvantages.

Chapter twelve is entitled as "English Education Policy in Saudi Arabia: English Language Education Policy in the Kingdom of Saudi Arabia: Current Trends, Issues and Challenges". In this chapter, Osman Z. Barnawi and Sajjadullah Al-Hawsawi bring a critical examination to the state of English language and English language policies and practices in the country. While doing this, the authors underline the aim of fostering general literacy in English in a successful way, internationalizing the education system and conserving national cultural identity. Starting with a historical overview of English language teaching, the authors also talk about the situation of English language education at intermediate schools, secondary schools, and higher education institutes.

The authors of chapter thirteen, "Education Interrupted: English Education Policy from the Rubble in Syria", Rabia Hos and Ibrahim Cinar provide information about the political, ethnic, social, economic, and geographical characteristic of Syria in an interrelated manner. The authors also take into consideration the civil unrest and vast breakdown experienced in Syria after the Arab Spring which broke out in 2010 . 
The previous and current situations of education generally and English language policy specifically are examined throughout the chapter.

In chapter fourteen, "English Education Policy in Turkey", Yasemin Kırkgöz examines English language education within a global perspective in relation with the major educational reforms in Turkey while she brings a micro-level perspective by giving educational outcomes of language planning and policies in the country. Principally making use of the six-point language-in-education planning framework of Kaplan and Baldauf (1997, 2003), the author discusses the effects of geographical and historical context of the country on language planning and policy, the policy of introducing English as medium of instruction, role of stakeholders who are responsible for language policy, and some insights about implementation and outcomes of language policy. The author describes the case of a state university where she teaches in order to concentrate on the effects of globalization and internationalization at institutions of higher education within a micro-level perspective. Examining English language planning and policy and the practice of English as the medium of instruction in connection with the remarkable educational reforms at all levels of primary, secondary and higher education make the chapter a comprehensive one.

Samira Boukadi and Salah Troudi entitled chapter fifteen as "English Education Policy in Tunisia, Issues of Language Policy in Post-revolution Tunisia". In this chapter, the position of recent language policies is discussed and the need for English as a global language is emphasized in spite of the existing problems in English language teaching at schools and in the society. The chapter also criticizes the reality that the requirements of English language learning are not taken into consideration by policymakers. Language policy and the linguistic situation in the country are examined extensively via inclusion of educational, socio-cultural, socio-economic, political, and educational perspectives.

"National Pride and the New School Model: English Language Education in Abu $D h a b i, U A E$ " is the title of chapter sixteen. In this chapter, Fiona S. Baker examines English language policy in the United Arab Emirates as the sixth wealthiest country in the world and gives information about the importance of English and bilingual education practices. With the aim of focusing on the English language policy, the present factors and agencies in the country are under investigation and equally future visions and plans are included in the chapter. The author makes a conclusion about the English language policy in the country in relation to immersion and bilingual models and puts forward certain suggestions.

Consequently, this book can be regarded as a distinctive one in several aspects. Firstly and mainly, it helps the reader draw the current picture of English Language Education Policy in several expanding circle countries (Kachru, 1985) of the Middle East and North Africa which are volatile in language policies. Additionally, this book is a comprehensive one as it talks about English language education policies and practices with the samples of 15 countries in the target region. Another distinctive 
feature of the book is that it offers the option of examining a specific country in the Middle East and North Africa region or examining all counties at once as the book is prepared with a modular design and each chapter is allocated for a country. Furthermore, the chapters talk about all levels of primary, secondary and higher education in several countries of the region and include English language practices and implementations experienced in these countries. However, some chapters of the book fail to cover all education levels and this causes a discrepancy between the chapters. Some chapters strike a critical manner while some chapters possess a descriptive manner. A more critical manner for the current situation of English language policy in the MENA countries would have been more effective to talk about "the power relations, ideological manipulations, and hegemony" in those countries (Rahimi \& Sahragard, 2007, p. 1). On the whole, this book can be regarded as a reference book for scholars, educators, administrators, program developers, educational and applied linguists and other stakeholders who are concerned with English language policy in the MENA countries.

\section{References}

Kachru, B. (1985). Standards, codification and sociolinguistic realism: The English language in the outer circle. In R. Quirk \& H. Widdowson (Eds.), English in the world (pp. 11-30). Cambridge: Cambridge University Press.

Kaplan, R. B., \& Baldauf, R. B., Jr. (1997). Language planning: From practice to theory. Clevedon: Multilingual Matters.

Kaplan, R. B., \& Baldauf, R. B., Jr. (2003). Language and language-in-education planning in the Pacific Basin. Dordrecht: Kluwer.

Rahimi, A., \& Sahragard, R. (2007). Critical discourse analysis. Tehran: Jungle Publications.

Tsui, A. B. M., \& Tollefson, J. W. (2007). Language policy, culture, and identity in Asian contexts. London: Taylor \& Francis.

\section{Copyrights}

Copyright for this article is retained by the author(s), with first publication rights granted to the Journal.

This is an open-access article distributed under the terms and conditions of the Creative Commons Attribution license (CC BY-NC-ND) (http://creativecommons.org/licenses/by-nc-nd/4.0/). 